\title{
THE EFFECT OF IONIZING RADIATIONS UPON THE RESPIRATION AND OXIDASES OF THE POTATO TUBER ${ }^{1}$
}

\author{
ALFRED S. SUSSMAN \\ Department of Botany, Vniversity of Michigan, Ann Arbor \\ AND \\ Biology Department, Brookhaven National Laboratory, \\ Upton, Long Island, New York
}

FOUR FIGURFS

There have been few recent and critical investigations dealing with the effect of ionizing radiations upon higher plant metabolism. The work that has been done was either concerned with microorganisms (Giese, '42, '47) or with hormonal effects on higher plants (cf. p. 38 of the review by Sparrow and Rubin, '52). Therefore, it was the purpose of the following experiments to determine the effect of radiations upon the metabolism of the potato tuber, as expressed by its respiratory rate, and by the activity of its oxidases.

\section{MATERIALS AND METHODS}

The tubers used in these experiments were of the Irish Cobbler variety and were approximately $1 \frac{11}{2}$ in diameter. It was necessary to use such small tubers because of the size restrictions imposed by the irradiation techniques used. They

'I would like to thank Dr. Arnold H. Sparrow for his encouragement and help given during the course of this work, as well as Mr. Erie C. Christensen who provided valuable assistance in the procuring of materials and in the accomplishment of the irradiation. Also, Dr. Raymond Klein provided valuable diseussion and materials for the pursuit of certain of these experiments. 
were stored at room temperature and in all cases were used less than 60 days after being harvested in July. In computing the tuber volumes for the purpose of calculating the flask constants in respirometric experiments, a density of 1.12 was used.

Respirometric experiments were carried out using modified Warburg vessels of approximately $80 \mathrm{ml}$ capacity. The tubers were equilibrated to the temperature of the water bath $\left(28^{\circ} \mathrm{C}\right.$.) for 60 minutes after which the $\mathrm{CO}_{2}$ output was measured for 60 minutes by the direct method. Oxygen consumption was then measured at 10 minute intervals for 60 minutes. It was assumed that the equilibration period was sufficient since linear rates were obtained. At least 6 tubers were used in each experiment and the values for the $Q_{\mathrm{O}_{2}} "$ and $\mathrm{Q}_{\mathrm{CO}_{2}}$ which are reported represent the average of these samples.

Cytochrome oxidase and tyrosinase activity were determined using the manometric techniques described by Goddard and Holden ('50). Warburg vessels of $17 \mathrm{ml}$ capacity were used in these experiments, and were shaken at a rate of 120 oscillations per minute at $28^{\circ} \mathrm{C}$. The enzyme preparations were made by chopping the potatoes with an equal volume of cold $0.1 \mathrm{M}$ sodium veronal buffer, pH 7.1, in a Waring blendor for 5 minutes. This "brei" was filtered through cheese cloth and the filtrate centrifuged at $500 \times$ gravity for 10 minutes. In order to measure cytochrome oxidase activity an aliquot of this supernatant was diluted with an equal volume of $0.1 \mathrm{M}$ phosphate buffer, $\mathrm{pH} 7.1$, and used in the respirometric determination. Tyrosinase activity was measured after diluting another aliquot of the supernatant with $20 \mathrm{vol}$ umes of $0.1 \mathrm{M}$ phosphate buffer, $\mathrm{pH} 6.8$.

Irradiation with gamma rays was accomplished by exposure to Tantalum ${ }^{182}$ sources delivering about 80,000 to $200,000 \mathrm{r}$ per hour. The tubers were handled as described by Manowitz ('51) : an aluminum tube about 12 " in length and 112" in diameter was used as a container for the potatoes during exposure.

\footnotetext{
${ }^{2} \mathrm{Q}_{\mathrm{O}_{2}}$ as used in these experiments is equivalent to $\mathrm{mm}^{\mathrm{3}} \mathrm{O}_{2} /$ hour $/ \mathrm{mg}$ fresh weight; $\mathrm{Q}_{\mathrm{CO}_{2}}$ is equivalent to $\mathrm{mm}^{2} \mathrm{CO}_{2} /$ hour $/ \mathrm{mg}$ fresh weight.
} 
Calibration of the source was accomplished by means of the techniques outlined in Weiss ('52). Doses of $100 \mathrm{r}$ ' were obtained by exposing the tubers to a Cobalt ${ }^{60}$ source in the Brookhaven "Gamma Field" deseribed by Sparrow and Singleton ('52).

The $\mathrm{x}$-ray source was a G.E. Maxitron 250 with a beryllium window tube, delivering $50,000 \mathrm{r}$ at $23 \mathrm{~cm}$ Target to Subject Distance (TST) at a rate of $1428 \mathrm{r}$ per minute. The Half Value (HVL) was $0.2 \mathrm{~mm}$ of copper, and the dosage was measured in air with a Victoreen Integron dosimeter. During irradiation, the potatoes were rotated in order to insure equal penetration to all tissues.

\section{RESULTS}

The respiratory gas exchange of tubers was determined immediately before irradiation and periodically thereafter. The effect of such treatment upon the $Q_{0_{2}}$ of potato tubers is shown in figure 1. In all cases there was an imme-

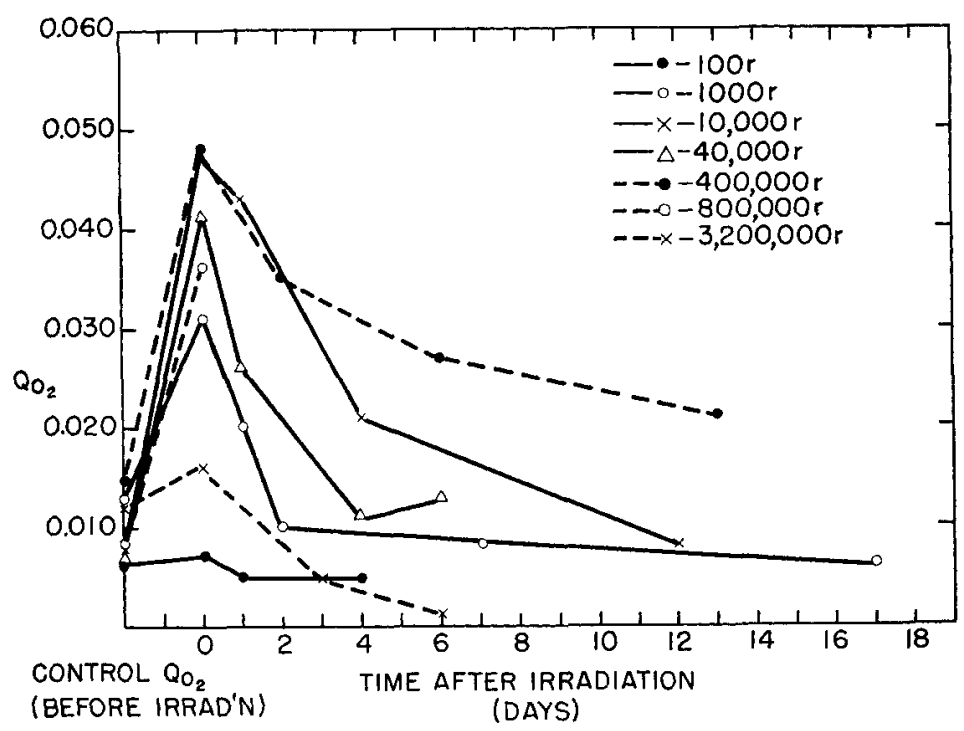

Fig. 1 The effect of gamma-irradiation upon the oxygen uptake of potato tubers. ( $\mathrm{Q}_{\mathrm{O}_{2}}$ calculated as mean of 6 tubers.) 
diate increase (0- day reading) in oxygen uptake which was approximately fivefold at dosages between 10,000 to $400,000 \mathrm{r}$ and two- to threefold at $1000 \mathrm{r}$ and $3,200,000 \mathrm{r}$. There was a slight increase at $100 \mathrm{r}$ but a "chi-squared" test showed that this was not significant. At all dosages except the highest, the $Q_{02}$ decreased after the first day and, in most cases, gradu-

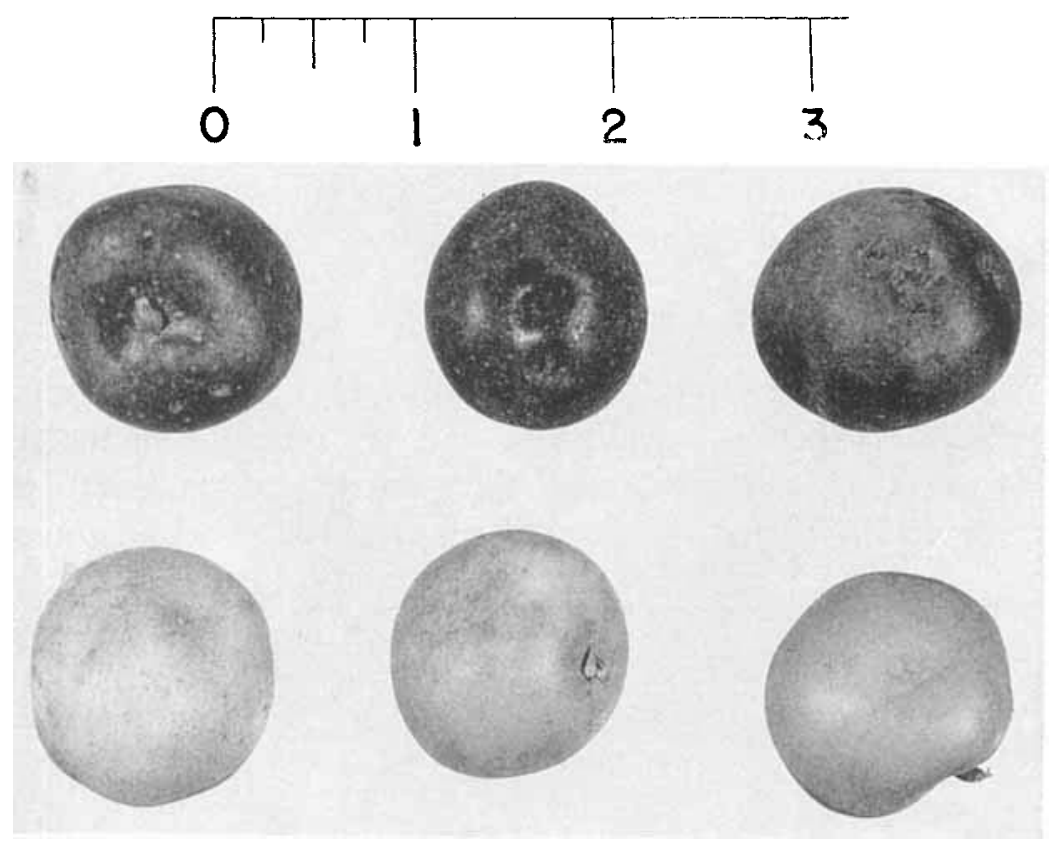

Fig. 2 The appearance of potato tubers 72 hours after receiving $3,200,000 \mathrm{r}$ gamma rays. (Seale in inches.) Top row contains the treated tubers while the bottom contains untreated controls.

ally returned to the control rate or to a rate slightly below this. At 3,200,000 r, however, the $Q_{02}$ at the end of 6 days after irradiation was low enough to suggest the total disruption of the potato's metabolism. This respiratory change was accompanied by the gradual blackening and softening of the tuber, as is shown in figure 2. Such visible changes began immediately after irradiation with the appearance of bluishblack spots over the epidermal surface as well as with a 
slight darkening of the entire tuber. Samples from the cortex, epidermis, and vascular region of these tubers were sectioned immediately after irradiation but no evidence of necrosis or other tissue injury was discovered. ${ }^{3}$

The effect of irradiation upon the $\mathrm{Q}_{\mathrm{CO}_{2}}$ of tubers is shown in figure 3. As in the case of the $\mathrm{Q}_{\mathrm{O} 2}$, the $\mathrm{Q}_{\mathrm{CO}_{2}}$ was also increased immediately after irradiation, although the magnitude of this

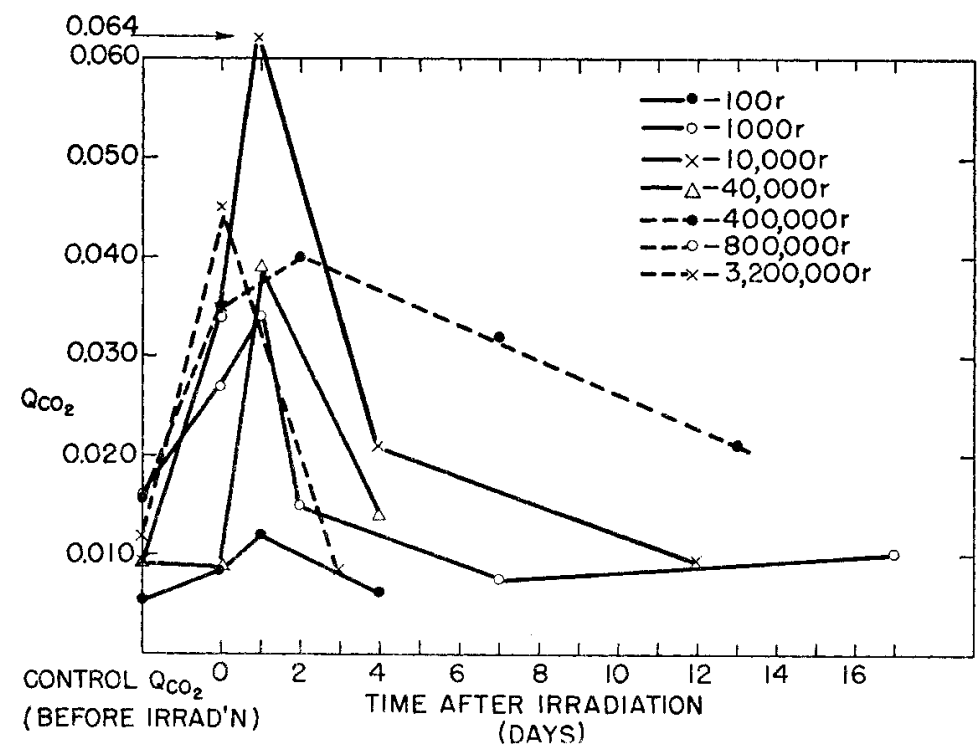

Fig. 3 The effect of gamma-irradiation upon the output of carbon dioxide by potato tubers. ( $Q_{\mathrm{CO}}$ calculated as mean of 6 tubers.)

increase was usually much smaller than in the former case. It was only during the second day after irradiation that the peak of the increase in $\mathrm{CO}_{2}$ production was reached. This is very evident when the data are plotted as in figure 4. Thereafter, however, this rate decreased more or less parallel to the $Q_{\mathrm{O}_{2}}$. In the case of the $100 \mathrm{r}$ and the 3,200,000 r treated tubers the $\mathrm{Q}_{\mathrm{CO}_{2}}$ increased more than did the $\mathrm{Q}_{\mathrm{O} 2}$. In the latter case there was

"The sectioning reported here was performed by Dr. James Gunckel and Miss Ielene Morrow who also checked the author's observations of the irradiated tissue. 
about a threefold differences between these increases but in the former the difference was only about one-third of this. In order to determine whether ammonia was being evolved by tubers irradiated with $3,200,000 \mathrm{r}, 0.5 \mathrm{ml}$ of $10 \% \mathrm{HCl}$ was used in the side-arm instead of water but there was no difference in the amounts of gas evolved. Ammonia analyses run in the Van Slyke apparatus were likewise negative. Moreover,

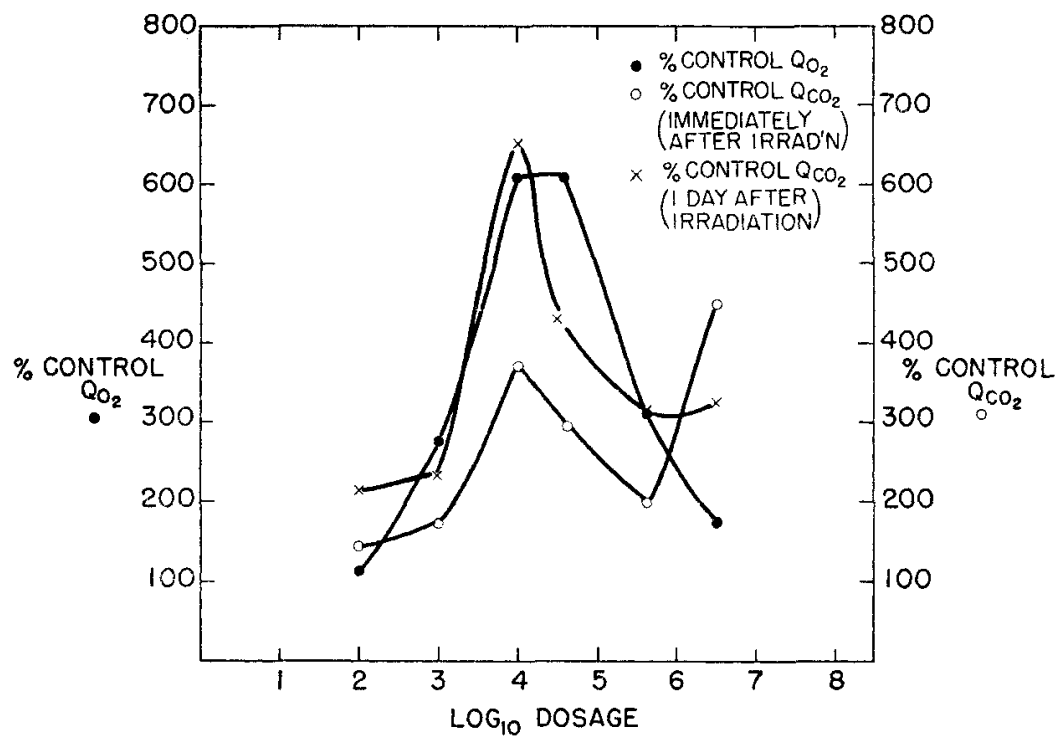

Fig. 4 The effect of gamma-irradiation upon the $Q_{o_{2}}$ and $Q_{\text {co. }}$ of potatoes as a function of dosage and time after irradiation.

a mixture of $\mathrm{AgNO}_{3}$ and $\mathrm{HNO}_{3}$ was used in the side-arm in order to trap ethylene in case this gas was being produced but again negative results were obtained. The $\mathrm{pH}$ of "breis" prepared from control tubers and those irradiated with $3,200,000 \mathrm{r}$ was measured by the use of a Beckmann $\mathrm{pH}$ meter in order to determine whether such changes could account for the increase in the amount of $\mathrm{CO}_{2}$ liberated by the treated tubers. About $50 \mathrm{ml}$ of potato tissue were ground for one minute in a Waring blendor and filtered through cheese cloth. The $\mathrm{pH}$ of both control and treated tubers was 6.0. 
Tubers were also exposed to X-irradiation and, in general, the same results were obtained as in the case of those that were irradiated with gamma rays. These results are given in table 1 .

TABLE' 1

The effect of $x$ rays upon the respiration of potato tubers

\begin{tabular}{|c|c|c|c|c|c|c|}
\hline \multirow{3}{*}{$\begin{array}{c}\operatorname{DOSAGE} \\
(\boldsymbol{r})\end{array}$} & \multirow{2}{*}{\multicolumn{2}{|c|}{ CONTROL }} & \multicolumn{4}{|c|}{ DAYS AFTER IRRADIATION } \\
\hline & & & \multicolumn{2}{|c|}{0} & \multicolumn{2}{|c|}{2} \\
\hline & $Q_{02}$ & $\mathrm{Q}_{\mathrm{Co}_{2}}$ & $\mathrm{Q}_{\mathrm{O}_{2}}$ & $\mathrm{Q}_{\mathrm{Co}}$ & $\bar{Q}_{0_{2}}$ & $\overline{Q_{\mathrm{CO}_{2}}}$ \\
\hline 50,000 & 0.011 & 0.011 & 0.042 & 0.022 & 0.034 & 0.046 \\
\hline 500,000 & 0.006 & $\ldots$ & 0.040 & 0.039 & $\ldots$ & \\
\hline
\end{tabular}

Finally, the cytochrome oxidase and tryrosinase activities of irradiated tubers were measured with the results shown in table 2. No significant effect upon the activity of these enzymes could be demonstrated immediately after irradiation

TABLE 2

The effect of gamma $(\gamma)$ and $x$ rays upon the cytochrome oxidase and tyrosinase activity of potato tubers

\begin{tabular}{cccc}
\hline $\begin{array}{c}\text { DOSAGE } \\
(r)\end{array}$ & $\begin{array}{c}\text { TYPE OF } \\
\text { RADIATION }\end{array}$ & $\begin{array}{c}\text { OYTOCHROME OXIDASE } \\
\text { ACTIVITY }\end{array}$ & $\begin{array}{c}\text { TYROSINASE } \\
\text { ACTVITY }\end{array}$ \\
\hline & & $m m^{3} O_{2} / 30$ minutes & $m^{3} \mathrm{O}_{2} / 30$ minutes \\
Control & $\cdots$ & 119,108 & 225 \\
40,000 & $\gamma$ rays & 114,117 & 220,200 \\
400,000 & $\gamma$ rays & 100 & 200 \\
$3,200,000$ & $\gamma$ rays & 122 & 90,110 \\
50,000 & Xrays & 94 & 212 \\
\hline
\end{tabular}

except in the case of the tubers exposed to $3,200,000 \mathrm{r}$. At this dose, there was about a $50 \%$ decrease in tyrosinase activity, although cytochrome oxidase activity was relatively unimpaired.

DISCUSSION AND CONCLUSIONS

It has been demonstrated that respiratory gas exchange in potato tubers is markedly enhanced by dosages of gamma irradiation as low as $1000 \mathrm{r}$. The effect upon the $Q_{0_{2}}$ is almost immediate in that increases from two- to sixfold were measureable several hours after the tubers were irradiated. There- 
after, a progressive decrease in the oxygen uptake oceurred. Similar increases in the $Q_{\mathrm{CO} 2}$ were also noted except that the peak of this increase occurred on the first day after irradiation. After this, the $\mathrm{Q}_{\mathrm{CO} 2}$ decreased in a manner parallel to the $\mathrm{Q}_{\mathrm{O}_{2}}$.

Previous work upon the metabolic effects of radiations on higher plants has shown that such treatment increases the rate of $\mathrm{CO}_{2}$ production by radish seeds and seedlings (Redfield and Bright, '22; Chesley, '34). On the other hand, Chesley cites several references wherein no increase of this kind could be observed, while Johnson ('26) also found that the $\mathrm{CO}_{2}$ production of seeds and young seedlings of Helianthus produced less $\mathrm{CO}_{2}$ as a result of $\mathrm{X}$-irradiation.

The literature bearing on the metabolic response of animals to irradiation also shows several well-established cases of increases in gas exchange (cf. Wynd and Reynolds, '35). For example increases in the oxygen uptake, as a result of $\mathrm{X}$ irradiation, were noted in frog skin (Williams and Sheard, '32), fowl erythrocytes (Frankenthal and Back, '44), grasshopper eggs (Tahmisian, '49), and in rats (Kirschner, Prosser, and Quastler, '49). That such increases can also be observed in homogenates was shown by Richmond ('51) using bone marrow and by Kunckel and Phillips ('52) who used rat liver. However, divergent results were obtained by Hevesy and Forssberg ('51) who found that X-irradiated mice exhaled less $\mathrm{CO}_{2}$ than did controls; moreover, Klein ('כ2) also failed to get any increases in the oxygen uptake of erythrocytes from X-irradiated ducks.

Such discrepancies have also arisen during studies on the effect of radiations on microorganisms (cf. brief review in Giese, '42). A possible explanation for some of these differences has been suggested by Giese ('42, '47) as a result of his work on yeast. Ultra-violet irradiation of these organisms was found to increase the rate of endogenous respiration more than tenfold although the rate of exogenous respiration was decreased under the same conditions. Similar results were recently obtained with Chlorella (Redford and 
Myers, '51) although the increase in the endogenous rate was only transitory.

Since the present experiments were performed with freshly harvested potato tubers these were probably in the dormant state. This was confirmed by germination tests which showed that unirradiated tubers used in these experiments developed shoots under greenhouse conditions only after $4-6$ months. It seems possible, although no confirmatory experiments have been carried out, that more rapidly metabolizing potatoes will show different responses to irradiation than did these.

Attempts have been made to explain the mechanism by which respiratory increases arise due to irradiation but these are largely speculative. Tentatively, a reasonable explanation might assume the production of a substance or substances which permit the cell to metabolize its available food reserves more rapidly than could be done before irradiation. That such changes may be connected to phosphate metabolism is suggested by Giese's ('47) results which showed that dinitrophenol (DNP) accelerated the rate of endogenous metabolism in yeast as well as synergistically increasing the oxygen uptake of irradiated cells. Further experiments along these lines are now being conducted in this laboratory in an attempt to explain the results obtained with potatoes.

It should also be noted that the respiratory systems of potatoes are much more resistant to irradiation than is the capacity for growth as judged by germination. Sparrow and Christensen ('50) have showed that exposure to $4800 \mathrm{r}$ gamma irradiation almost entirely prevented the germination of potato pieces whereas the respiration of the tubers used in the present experiments continued for indefinite periods after almost 100 times this dosage. The results of germination tests during the present experinents largely confirm the previous findings.

The maintenance of cytochrome oxidase activity at approximately the same level after receiving all the dosages administered during these experiments suggests that the mechanism of radiation damage to growth must be sought elsewhere. 
Similarly, tyrosinase activity remains constant until tubers are exposed to $3,200,000 \mathrm{r}$ so that changes in this enzyme's activity cannot be directly connected with the observed changes in metabolic rate and germinability. However, the blackening of the tubers given $3,200,000 \mathrm{r}$, accompanied by the decrease in tyrosinase activity, suggest a possible relationship. Since the products of this enzyme's activity are known to poison it (Nelson and Dawson, '44), it is conceivable that the blackening of the tubers is due to the accumulation of these products with subsequent injury to the enzyme.

\section{SUMMARY}

1. Potato tubers (Irish Cobbler variety) show increases in Q.: up to $600 \%$ as a result of gamma ray irradiation over a wide range of dosages.

2. Carbon dioxide evolution is also increased although the peak of this increase occurs 24 hours after that of the oxygen uptake.

3. Cytochrome oxidase and tyrosinase activities were not affected by the dosages used in these experiments except that the latter enzyme lost half of its activity at 3,200,000 r.

\section{LITERATURE CITED}

ChesLex, J. C. 1934 The effect of radiation on rell respiration. Biol. Bunl, $6 \%$ : $259-272$.

FrankenthaL, I., AND A. Back 1944 The effect of X-rays on the respiration of fowl erythrocytes. Bioch. J., 38: 351-354.

Gikse, A. C. 1942 Stimulation of yeast respiration by ultraviolet radiations. J. Cell. and Comp. Physiol., g0: 35-46.

Gifse, A. C., AND W. H. Swanson 1947 Studies on the respiration of yeast after irradiation with ultraviolet light. J. Cell. and Comp. Physiol., 30: $285-301$.

Goddard, D. R., and C. Holden 1950 Cytochrome oxidase in the potato tuber. Arch. Bioch., 27: 41-47.

Hevesy, G., AND A. Forssberg 1951 Effect of irradiation by X-rays on the exhalation of carbon dioxide by the monse. Nature, 168 (4275): 6 ?

Johnson, F. L. 1926 Effect of $X$-rays on growth, development, and oxidizing enzymes of Helianthus annuis. Bot. Gaz., 82: 373-440.

Kirschner, I. B., C. L. Prosser and H. Quastuer 1949 Increased metaholie rate in rats after $\mathrm{X}$-irradiation. Proc. Soc. Exp. Biol. and Med., $z$ : $463-467$. 
KLEIN, J. R. 1952 Decrease in the oxygen uptake of duck erythrocytes following whole-body X-irradiation. Fed. Proc., 11: 240.

KUNCKer, H. O., AND P. H. PHillips 1952 Choline oxidase and endogenous respiration in liver homogenates from $X$-irradiated rats. Arch. Bioch. and Biophys., 37 : 366-374.

Manowimz, B. 1951 Use of kilocurie radiation sources. Nucleonies, 9: 10-13.

Netson, J. M., AND C. R. DAwson 1944 Tyrosinase. Adv. in Enzymol., 4 : 99-152.

ReDfield, A. C., AND E. M. BRIGHT 1922 The effects of radium rays on metabolism and growth in seeds. J. Gen. Physiol., 4: 297-301.

REDFORD, E. L., AND J. MYrRs 1951 Some effects of ultraviolet radiations on the metabolism of Chlorella. J. Cell. and Comp. Physiol, 38: 217243.

RICHMOND, J. E., K. I. ALTMAN AND K. SALOMon 1.951 The relation of oxygen uptake to hemoglobin synthesis. Science, 113: 404-405.

SPARRow, A. H., AND B. A. RuBin 1952 Chapter in Survey of Biological Progress. Vol. 2: 1-52.

Sparkow, A. H., AND E. Chris'Tinsen 1950 Effects of X-ray, neutron, and ehronic gamma irradiation on growth and yield of potatoes. Am. J. Bot., 37: 667 .

Sparrow, A. H., AND W. R. Singlieton 1952 The use of radiocobalt as a source of gamma rays and some effects of chronic irradiation on growing plants. Am. Nat., in press.

Tanmisian, T. N. 1949 The effect of $\mathrm{X}$-radiation on the metabolic processes of the resting cell. J. Exp. Zool., 112: 449-463.

WEISs, J. 1952 Chemical dosimetry using ferrous and ceric sulphates. Nucleonies, $10: 28-31$.

WILtiams, M. M. D., AND C. SHEARD 1932 Increased oxidation in irradiated frog skin. Protoplasma, $15: 396-414$.

WYND, F. L., AND E. S. REYNoLds 1935 Studies in ultra-violet and respiratory phenomena. I. Review of work published before 1935. Ann. Missouri Bot. Gard., 22: 771-835. 